Time Series Analysis 



\section{Time Series Analysis}

James D. Hamilton 
Copyright (C) 1994 by Princeton University Press

Published by Princeton University Press, 41 William St.

Princeton, New Jersey 08540

In the United Kingdom: Princeton University Press,

Chichester, West Sussex

\section{All Rights Reserved}

\section{Library of Congress Cataloging-in-Publication Data}

Hamilton, James D. (James Douglas), (1954-)

Time series analysis / James D. Hamilton.

p. $\mathrm{cm}$.

Includes bibliographical references and indexes.

ISBN-13: 978-0-691-04289-3 (cloth)

ISBN-10: 0-691-04289-6 (cloth)

1. Time-series analysis. I. Title

QA280.H264 1994

$519.5^{\prime} 5-\mathrm{dc} 20 \quad 93-4958$

CIP

This book has been composed in Times Roman.

Princeton University Press books are printed on acid-free paper and meet the guidelines for permanence and durability of the Committee on Production Guidelines for Book Longevity of the Council on Library Resources.

http://pup.princeton.edu

Printed in the United States of America

$2019 \quad 1817 \quad 16 \quad 15$ 